УДК $82.0: 159.9$

Мкртчян Т.В. аспірантка кафедри української та світової літератур КПІ ДВНЗ «Криворізький національний університет»

\title{
ПСИХОТИП ПЕРСОНАЖА
}

\section{ЯК ЛІТЕРАТУРОЗНАВЧА ПРОБЛЕМА}

У статті здійснено огляд деяких праџь психологів та літературознавиів, в яких йшла мова про сутність поняття «психотип». 
Авторка статті систематизувала погляди на стандартизацію психотипу взагалі. Аналітичний огляд праџь літературознавиів підтвердив те, щзо проблема психотипів персонажів потребує трунтовного вивчення.

Ключові слова: психотип, персонаж, конструювання.

В статье проанализированы некоторые труды психологов $u$ литературоведов, в которых идёт речь о сущности понятия «психотип». Автор статьи систематизировала взгляды на стандартизацию психотипа вообще. Аналитический обзор трудов литературоведов подтвердил то, что проблема психотипов персонажей требует основательного изучения.

Ключевые слова: психотип, персонаж, конструирование.

In the article to analyse some works psychologist and specialist in study of literature about essence concept psychotype. The auther article to systematize look to standardization psychotype. The analytical survey specialist in study of literature works to confirm problem psychotype character demand well-founded study.

Keywords: psychotype, character, to constitute.

Проблему психотипів людей взагалі і персонажів зокрема порушив у низці праць літературознавець А. В. Козлов, який спробував обгрунтувати історію виникнення, розвитку цього поняття.

Так, у статті «Психотипи викладачів у ВНЗ» учений акцентував увагу на тому, що «... щее в $V \mathrm{~cm}$. вперше надзвичайно важливу й актуальну проблему психотипів людей порушив Пруденщій у поемі «Психомахія», дослідженням якої займаються вчені світу, але чи не найстабільніше дослідники Прінстона (США)» [Козлов 2010:207]. На думку літературознавця, у визначенні психотипу потрібно брати до уваги такі основні фактори, як тип переживання та психіки людини.

Мета статті полягає у тому, щоб методом аналітичного огляду необхідної літератури сформувати сутність поняття «психотип» персонажа.

Відштовхуючись від визначення «типу» (зразок, модель, форма, яким відповідає певна група предметів, явищ тощо), можна твердити, що 
психотип людини - це також своєрідна модель або зразок, в якому узагальнено низку рис характеру, проявів поведінки та емоцій людини у різних життєвих ситуаціях. Довгий час у літературознавчій думці тип характеру персонажа визначали за тими основними рисами характеру, які презентував ще у V ст. до. н. е Теофраст у праці «Про характери». Проте у 1941 році російський літературознавець О. Фрейденберг помітила, що праця Теофраста «Про характери» - це перша спроба класифікувати людей за основними типами психіки, яких, на думку дослідниці, у зазначеній праці два - «люди з недоліками» та «люди без недоліків». Відповідно такі риси, як улесливість, честолюбство, пліткарство свідчать про те, що перед нами тип людини з суттєвими недоліками, а щедрість, добродушність, відкритість вказують на людину протилежного типу.

Нині деякі учені ведуть мову про те, що психотипи формуються роками і вони вічні та незмінні. Проте така думка поки що не отримала належного обгрунтування у науці, адже той чи інший психотип піддається впливам часу, змінюються умови, в яких він формується, а відповідно міняються домінанти емоцій.

Наприклад, відомий ще 3 XVII ст. трикстерський тип поведінки персонажа усталено порушував існуючі морально-етичні норми. Психотип трикстера включав такий традиційний набір рис: шахрайство, хитрість, бажання ошукати когось тощо.

На думку Р. Кулєшова, «міфологема трикстеріади трансформується в процесі зміни культурних парадигм, щуо визначає різний за змістом та кількістю комплекс ознак трикстера у різні епохи. Проте, незважаючи на наявність безлічі сочіокультурних варіантів маніфестацій трикстера, його архетипічна основа виявляється в певному сталому комплексі характеристик цього образу у літературі та кінематографi» [Кулєшов 2008:3]. I вже сьогодні цей тип поведінки став 
більш осучасненим, прилаштованим до реалій сьогодення, до тих цінностей, якими живе те чи інше суспільство.

Нині сучасна психологія вивчає такі психотипи людей, як психотип кар'єриста / кар'єристки, психотип дівчинки-ванільки, психотип пристосуванця, психотип підприємця та багато інших. Усі вказані психотипи враховують тип темпераменту, умови формування психіки людини, процес виховання тощо. Психотипи диференціюють за приналежністю до статті - психотипи жінок, психотипи чоловіків; за віковими особливостями - психтипи дітей, юнаків, психотипи за наявністю родинних зв'язків - психотип бабусі, психотип дідуся тощо. Внутрішня диференціація існує всередині кожного психотипу, наприклад, психотип бабусі-няні, бабусі-відьми, бабусі-змії тощо.

У літературі, яка є енциклопедією людинознавства, усі вказані й не вказані психотипи людей сконструйовані або ж конструюються упродовж усієї історії цього виду мистецтва.

Психотипи персонажів у творах одного й того ж письменника дуже часто є носіями авторської ідеї добра, ідеалу чи антиідеалу. Так, наприклад, у В. Винниченка дуже схожа поведінкова модель двох персонажів Федька («Федько-халамидник») та Костя («Комедія з Костем»).

Конструювання психотипу відбувається на основі уявлень і знань письменника про всі типи нервової системи, глибоке вивчення поведінки людей в конкретних життєвих ситуаціях, поведінки персонажа в соціумі, а це як відомо вимагає від письменника вміння «читати людину як книгу».

Окрім цього, на думку американського психолога Д. Холмса, письменник повинен навчитися розрізняти стійкі або по життєві форми поведінки і реакції особистості, від недовговічних епізодів порушеної поведінки [Холмс 2003].

Той чи інший психотип персонажа має ще риси ментальності того народу, в літературі якого він діє. Б. Салюк у статті «Бешкетництво-як- 
бунт. Проблема «Шибеник VS цивілізаці» у літературі для дітей i про дітей» проаналізував поведінкову модель персонажа бешкетника на матеріалі творів В. Винниченка, М. Твена та ін. При визначенні поведінкової моделі персонажа, на нашу думку, варто брати до уваги й особливості ментальності, тип нервової системи.

Так, наприклад, психотип дитячого персонажа хлопчика-розбишаки Гекельберрі Фінна і Федька-халамидника мають багато спільних рис у поведінці. Психотип хлопчика-розбишаки до якого можна віднести цих двох персонажів має відмінні ментальні особливості та різні умови виховання.

Як відомо, Федько-халамидник ріс у родинні, мав батька й матір, а Гекельберрі Фінн - обшарпаний безхатченко, син пияки, дитина, яка жила сама по собі. Те, як жив хлопчик, де він спав суспільству, в якому він ріс було абсолютно байдуже. Батьків дітей, які хотіли товаришувати 3 Гекельберрі Фіном, брав страх за своїх чад, бо на іiі думку цей обшарпанець негативно впливав на них. А ось діти по-своєму заздрили Геку, бо він був вільним і ніхто на нього не тиснув.

Про обох цих хлопчиків можна сказати - «камінь, а не дитина». Обидва винахідливі, загартовані життям, готові на самопожертву заради інших. За їхнім темпераментом обох хлопчиків можна віднести до холеричного типу нервової системи: непосидючі, рухливі, прудкі та жваві. А ще вони обидва життєво дуже мудрі, саме ця риса приваблювала до них увагу решти дітей. Проте ментальність цих двох персонажів суттєво позначається на їх поведінці в соціумі. Так, Гекельберрі Фінн, як і всі американці, схильний до авантюр, страшенний мрійник, здатний мислити раціоналістично. Федько теж авантюрист, але він скутий у своїх задумах через постійний контроль батьків.

Таким чином, аналізуючи основні складові елементи структури психотипу персонажа необхідно враховувати не тільки тип нервової 
системи, а й ментальність, геополітичні умови проживання, статус родини, стосунки в родинні між батьками, духовну ауру родинних взаємин, тобто спрямованість виховання дитини на добро- чи злотворення.

Нині така наука, як соціоніка визначила шістнадцять основних психотипів людей. Ця галузь знань переважно орієнтується на способи поведінки людини у соціумі, а відповідно й визначає їх приналежність до того чи іншого психотипу. Проте сутність поняття «психотип», на нашу думку, не обмежується тільки поведінкою людини в соціумі, а тут велику роль відіграє тип темпераменту, основні риси ментальності, риси характеру, умови виховання тощо.

На жаль, грунтовних літературознавчих досліджень проблеми аналізу психотипів персонажів поки що не здійснено. Так само потребує уважного й ретельного дослідження сутність конструювання схожих психотипів у літературах світу.

Отже, побіжний аналітичний огляд праць психологів та літературознавців показав, що проблема сутності писхотипу персонажа в літературі $\epsilon$ актуальною. Процес конструювання психотипу персонажа письменником базується на його знаннях про менталітет народу життя якого він зображує, типи темпераментів, основних емоційних домінантах психіки персонажа тощо.

\section{БІБЛІОГРАФІЯ}

Козлов 2011 - Козлов А. Основні психотипи викладачів ВН3 / А. Козлов // Педагогіка вищої та середньої школи ; за ред.. проф. В. К. Буряка. - Вип. 32. - Кривий Ріг, 2011. - С. 207-218.

Куєвда 2001 - Куєвда В. Т. Праісторичні чинники формування етнопсихотипу в контексті методологічних проблем етнопсихології. Проблеми загальної та педагогічної психології // Збірник наукових праць Інституту психології ім. Г. С. Костюка АПН України ; за ред. Максименка С. Д. - К., 2001. - Т. III, ч. 2. - С. 46-60. 


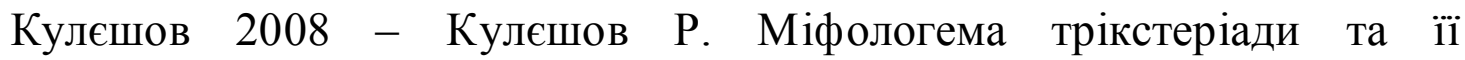
трансформація в пост класичній культурі: структурно-семіотичний аналіз: автореферат дисертації на здобуття наукового ступеня кандидат культурології зі спеціальності - 26.00.01 - теорія та історія культури. Харків, 2008. - 20 c.

Салюк 2013 - Салюк Б. Бешкетництво-як-бунт. Проблема «Шибеник VS цивілізація» у літературі для дітей і про дітей / Богдан Салюк // Режим доступу: urccyl.com.ua/fileadmin/user_upload/Visnyk/Visnyk_2013/Vis...

Холмс 2003 - Холмс Д. Анормальная психология / Девид Холмс. Спб. : Питер, 2003. - 304 с. 